\title{
Dynamic Changes in Gene Expression During Human Trophoblast Differentiation
}

\author{
Stuart Handwerger and Bruce Aronow \\ Departments of Endocrinology and Molecular and Developmental Biology, Children's Hospital \\ Research Foundation, and Department of Pediatrics, University of Cincinnati College of \\ Medicine, Cincinnati, Ohio 45229
}

\begin{abstract}
The genetic program that directs human placental differentiation is poorly understood. In a recent study, we used DNA microarray analyses to determine genes that are dynamically regulated during human placental development in an in vitro model system in which highly purified cytotrophoblast cells aggregate spontaneously and fuse to form a multinucleated syncytium that expresses placental lactogen, human chorionic gonadotropin, and other proteins normally expressed by fully differentiated syncytiotrophoblast cells. Of the 6918 genes present on the Incyte Human GEM V microarray that we analyzed over a 9-day period, 141 were induced and 256 were downregulated by more than 2-fold. The dynamically regulated genes fell into nine distinct kinetic patterns of induction or repression, as detected by the K-means algorithm. Classifying the genes according to functional characteristics, the regulated genes could be divided into six overall categories: cell and tissue structural dynamics, cell cycle and apoptosis, intercellular communication, metabolism, regulation of gene expression, and expressed sequence tags and function unknown. Gene expression changes within key functional categories were tightly coupled to the morphological changes that occurred during trophoblast differentiation. Within several key gene categories (e.g., cell and tissue structure), many genes were strongly activated, while others with related function were strongly repressed. These findings suggest that trophoblast differentiation is augmented by "categorical reprogramming" in which the ability of induced genes to function is enhanced by diminished synthesis of other genes within the same category. We also observed categorical reprogramming in human decidual fibroblasts decidualized in vitro in response to progesterone, estradiol, and cyclic AMP. While there was little overlap between genes that are dynamically regulated during trophoblast differentiation versus decidualization, many of the categories in which genes were strongly activated also contained genes whose expression was strongly diminished. Taken together, these findings point to a fundamental role for simultaneous induction and repression of mRNAs that encode functionally related proteins during the differentiation process.
\end{abstract}

\section{Introduction}

The placenta performs many different functions, including 1) exchange of substrates, gases, and other factors between the maternal and fetal circulations; and 2) synthesis and secretion of protein and steroid hormones, growth factors, and other substances vital for regulation of maternal and fetal metabolism and 
growth (Benirschke and Kaufmann, 1995). Most of these biologic actions occur at the trophoblast layer of the placental villous that is composed of two cell types: syncytiotrophoblasts and cytotrophoblasts. As shown in Figure 1, syncytiotrophoblast cells form the continuous, uninterrupted, multinucleated, epithelium-like surface of the placental villous that separates maternal blood from the villous interior. The mononuclear cytotrophoblast cells (Langhans' cells), which are located between the syncytiotrophoblast layer and its basement membrane, proliferate and fuse during trophoblast differentiation to form the overlying multinucleated syncytium (for review, see Benirschke and Kaufmann, 1995).

This chapter will present a brief overview of the differentiation of human cytotrophoblast cells to syncytiotrophoblast cells, emphasizing genes that are regulated during the differentiation process and factors that are known to regulate placental development. We then will present recent DNA microarray studies from our laboratory that have identified many previously unrecognized genes that

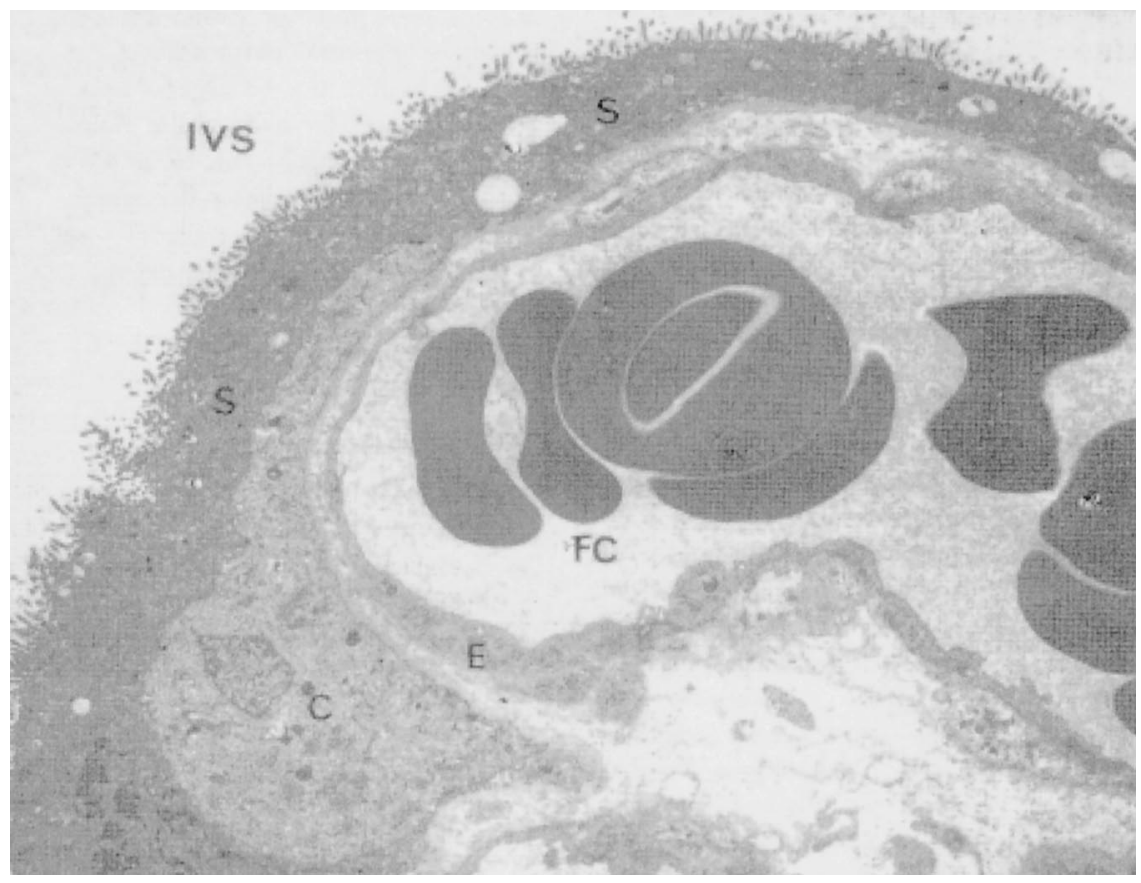

FIG. 1. Electron micrograph of a placental villous. IVS, intervillous space (containing maternal blood); S, syncytiotrophoblast; C, cytotrophoblast; E, endothelium; FC, fetal capillary lumen (containing fetal blood). Magnification, $\times$ 500. [Reprinted with permission from Sibley CP 1998 Placental nutrient transport. In Knobil E, Neill JD, eds. Encyclopedia of Reproduction. San Diego: Academic Press; 883.] 
are dynamically regulated during cytotrophoblast differentiation and their patterns of expression during the differentiation process. The data indicate that cytotrophoblast differentiation results from a dynamic genetic program in which some genes within specific functional groups are induced, while others within the same groups are repressed. The data provide insight into molecular mechanisms critical for the induction of this differentiation process.

\section{Dynamics of Placental Differentiation}

\section{A. DIFFERENTIATION SCHEME}

During mammalian embryogenesis, the first differentiation event in the blastocyst leads to the formation of trophoblast cells. Prior to this developmental stage, blastomeres are totipotent and may form either trophoblast cells or cells of the inner cell mass, which develop into the embryo. The placenta stem cell divides into the villous cytotrophoblast cell, which is the precursor of the syncytiotrophoblast cell, and the invasive extravillous trophoblast cell, which is the precursor for the column of trophoblast cells that invades the myometrium of the pregnant uterus and anchors the placenta. A schematic representation of the differentiation scheme and many of the factors known to induce or inhibit cytotrophoblast differentiation is depicted in Figure 2. Several excellent reviews that summarize the differentiation process in detail have been published (Morrish et al., 1998; Cross, 2000; Knofler et al., 2001).

\section{B. IN VITRO MODEL OF TROPHOBLAST DIFFERENTIATION}

The dynamics of cytotrophoblast differentiation have been studied using primary cultures of human trophoblast cells as a model system (Kliman et al., 1986; Ringler and Strauss, 1990, Richards et al., 1994). Highly purified preparations of mononucleated cytotrophoblast cells can be isolated from preterm and term placental tissue by enzymatic dispersion. The isolated cells from term placental tissue aggregate spontaneously in culture and fuse to form a multinucleated syncytiotrophoblast that synthesizes and secretes placental lactogen (hPL), chorionic gonadotropin (hCG), and other syncytiotrophoblast-specific protein and steroid hormones (Figure 3). These in vitro changes, which recapitulate important activities accomplished by normal cytotrophoblast cells during in vivo maturation, implicate a critical relationship between the differentiation of cytotrophoblast cells into syncytiotrophoblast cells and the induction of hPL, hCG, and several other placental hormones (Hoshina et al., 1984; Boime, 1991). Isolated cells from first-trimester placentas enter the invasive pathway. 


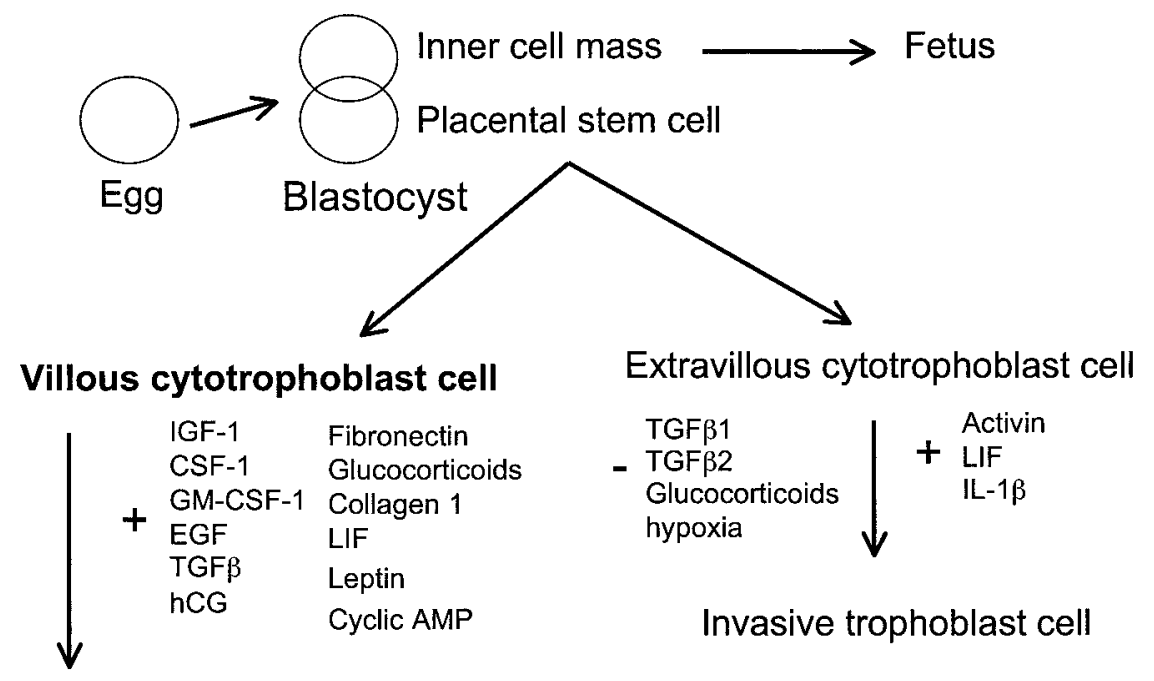

\section{Syncytiotrophoblast cell}

FIG. 2. Schematic representation of human placental development. Some of the factors that regulate the differentiation of villous and extravillous cytotrophoblast cells are indicated. The plus sign indicates stimulatory factors; the minus sign indicates inhibitory factors. IGF-1, insulin-like growth factor-1; CSF-1, colony-stimulating factor-1; GM, granulocyte/macrophage; EGF, epidermal growth factor; TGF $\beta$, transforming growth factor beta; hCG, chorionic gonadotropin; LIF, leukemia inhibitory factor; IL, interleukin.

\section{REGULATION OF TROPHOBLAST DIFFERENTIATION}

Villous cytotrophoblast cells can be induced to differentiate in vitro by epidermal growth factor (EGF) (Maruo et al., 1995a), hCG (Shi et al., 1993); leukemia inhibitory factor (LIF) (Bischof et al., 1995), colony-stimulating factor-1 (CSF-1) (Pollard et al., 1987), granulocyte/macrophage (GM)-CSF (Garcia-Lloret et al., 1994), insulin-like growth factor-I (IGF-I) (Maruo et al., 1995b), and cyclic AMP (cAMP) (Wice et al., 1990). Transforming growth factor beta $1\left(\mathrm{TGF} \beta_{1}\right)$ has been shown to inhibit cytotrophoblast differentiation in vitro (Morrish et al., 1991) and redirect the pathway of trophoblast differentiation from a villous syncytiotrophoblast phenotype to an anchoring phenotype (Feinberg et al., 1994; Nachtigall et al., 1996). Tumor necrosis factor-alpha (TNF- $\alpha$ ) and interferon-gamma (IFN- $\gamma$ ) induce trophoblast cell apoptosis in vitro, while EGF inhibits apoptosis (Morrish et al., 1991; Ho et al., 1999). The genetic program for trophoblast differentiation in the mouse has been shown to be regulated by several transcription factors, including HOXB6, HOXC5, HOXC6, HOX3E, HB24, GAX, MSX2, DLX4, 


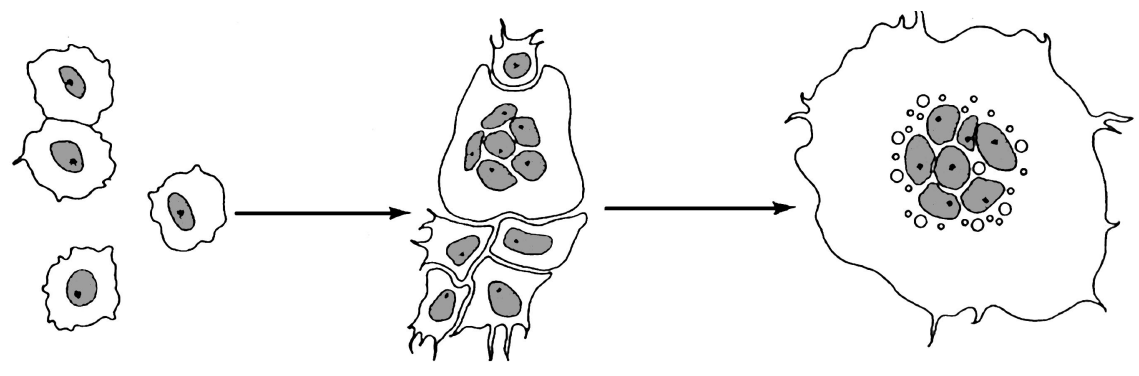

Day 1

Day 3

Day 5

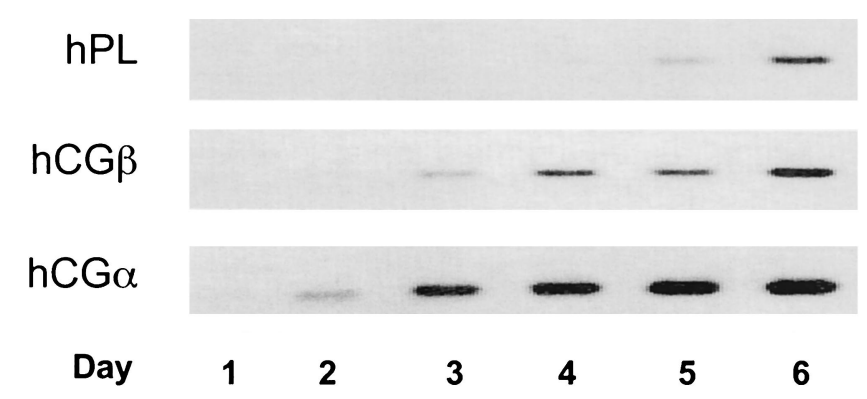

FIG. 3. Expression of placental lactogen (hPL), $\mathrm{hCG} \alpha$, and $\mathrm{hCG} \beta$ mRNAs during in vitro differentiation of human cytotrophoblast cells. By day 1, the isolated cytotrophoblast cells are beginning to aggregate. By day 3, many of the cells have fused to form a syncytium; by day 5, syncytialization is nearly complete. $\mathrm{HPL}, \mathrm{hCG} \alpha$, and $\mathrm{hCG} \beta$ mRNA levels were determined by Northern blot analysis. [Adapted with permission from Richards RG, Hartman SM, Handwerger S 1994 Human cytotrophoblast cells cultured in maternal serum progress to a differentiated syncytial phenotype expressing both human chorionic gonadotropin and human placental lactogen. Endocrinology 135:321-329. Copyright The Endocrine Society.]

Pit-1, TF-1, TEF5, and c-Ets1 (Scott et al., 2000). However, the genetic program that controls trophoblast lineage determination and villous cytotrophoblast cell differentiation into syncytiotrophoblast cells is poorly understood. In addition, little is known about the genes that are induced and repressed during the differentiation process. Studies from our laboratory suggest that human cytotrophoblast differentiation is induced in vitro by retinoic acid receptor alpha (RAR $\alpha$ ) (Stephanou and Handwerger, 1995a), thyroid hormone receptor beta (TR $\beta$ ) (Stephanou and Handwerger, 1995a), nuclear factor-interleukin-6 (NF-IL6) (Stephanou and Handwerger, 1995b), and activator protein-2 alpha (AP-2 $\alpha$ ) (Richardson et al., 2001). 


\section{GENE EXPRESSION DURING TROPHOBLAST DIFFERENTIATION}

Several studies have begun to define groups of genes that are induced during placental differentiation. Morrish and coworkers (1996), using a subtraction cDNA library between undifferentiated and differentiating cytotrophoblast cells, identified six novel genes and four known syncytial products that are induced during differentiation (hCG $\alpha$, pregnancy-specific $\beta_{1}$ glycoprotein, $3 \beta$-hydroxysteroid dehydrogenase, plasminogen activator inhibitor (PAI) type I). Ten other genes were identified that increased during differentiation, five of which (keratin 19, calrectiulin, heat shock protein (HSP) 27, serum and glucocorticoid-regulated kinase, adrenomedullin) were not known previously to be expressed in placenta. The other induced genes included keratin 8 , fibronectin, mitochondrial adenosine triphosphate (ATP) synthase, and superoxide dismutase-1. Dizon-Townson and coworkers (2000) recently found 17 of 186 random clones of a cDNA library from first-trimester placenta represented potentially novel placental genes that have not been characterized. Using differential display analysis, Xu and coworkers (1999) identified seven genes induced in BeWo choriocarcinoma cells during in vitro differentiation in response to cAMP: cytochrome p450 IIC, inosine monophosphate dehydrogenase type II, reducing agent and tunicamycin-responsive protein, and four unknown genes.

\section{DNA Microarray Study of Villous Cytotrophoblast Differentiation}

\section{A. METHODS}

In order to identify genes that are dynamically regulated during placental development and their expression profiles during the differentiation process, we studied gene expression in primary cultures of highly purified trophoblast cells undergoing spontaneous differentiation (Aronow et al., 2001). The cytotrophoblast cells were prepared by enzymatic dispersion and purified to $>95 \%$ homogeneity by negative selection using a monoclonal antibody to CD9. The cells were cultured in medium containing human maternal serum, since earlier studies from our laboratory demonstrated that cytotrophoblast cells cultured in medium containing human maternal serum express greater amounts of hPL, hCG, and other proteins than cells cultured in other media (Richards et al., 1994). RNA was isolated from the trophoblast cells at 12 hours after plating (time 0), when the cells were adherent to the culture dish, and at 1,2,3,4, and 6 days of culture. Cy3- and Cy5-labeled probes were prepared and DNA microarrays were performed using the Incyte Human GemV microarray, which contains 6918 genes. Primary data were examined using Incyte Gemtools software and GeneSpring software (Silicon Genetics, Redwood City, CA). Each microarray contained 192 control genes present as nonmammalian, single-gene "spikes" or 
"complex targets" that consisted of probe-sets that contain a pool of cellular genes expressed in most cell types. In addition, each experimental mRNA sample was augmented with incremental amounts of nonmammalian gene RNA, to permit assessment of the dynamic range attained within each microarray. The reliability of microarray quantitative data was corroborated independently through reverse transcription-polymerase chain reaction (RT-PCR) or Northern blot analysis of the mRNAs used in the microarray experiments as well as by replicate analyses using additional cell and mRNA preparations.

\section{B. IDENTIFICATION OF REGULATED GENES}

DNA microarray analyses indicated that 397 of the nearly 7000 genes exhibited robust changes during differentiation, using the criteria of $\geq 2$-fold induction or repression relative to the day 0 sample. Of these, 141 were induced by $\geq 2$-fold and 256 were repressed by $\geq 50 \%$. The number of regulated genes increased progressively during in vitro differentiation. Overall, 93\% of the induced genes and $73 \%$ of the repressed genes exhibited changes at two or more time points. The 25 most-induced and repressed genes are shown in Table I. As will be discussed, many of the most-induced genes are involved in cell adhesion and extracellular matrix formation.

\section{KINETICS OF TROPHOBLAST DIFFERENTIATION}

Several different inductive and repressive kinetic patterns were associated with villous cytotrophoblast differentiation. Figure 4 shows the patterns of gene expression that were determined by mathematical clustering of the log-transformed normalized ratio values using hierarchical tree and K-means algorithms. The hierarchical tree structure revealed a major division between induced and repressed genes, with the principal variations within each major division attributable to the delay period prior to induction or repression. Using a K-means cluster analysis, we divided the expression patterns into nine distinct kinetic patterns (Figure 5). The patterns consisted of variable delays prior to the induction or repression of different groups of genes, with most gene groups exhibiting rapid initiation of their transcriptional pattern. Pattern 1 genes were induced strongly at day 1, then either slowed in their rate of accumulation or declined. Pattern 2 genes reached peak induction at day 2, then leveled or declined at later days. Genes in pattern groups 3 and 4 exhibited further time delays in their induction, increasing after the induction of the hPL and hCG genes. Patterns 5-9 were composed of repressed genes that exhibited varying delays prior to their decline. Only groups 4 and 6 exhibited a significant delay prior to initiation of induction or repression. Only three genes were repressed and subsequently induced; only two were initially activated and subsequently repressed. The distribution of 
TABLE I

The 25 Most-induced and Repressed Genes during Trophoblast Differentiation

\begin{tabular}{|c|c|c|c|c|c|}
\hline $\begin{array}{l}\text { Accession } \\
\text { number }\end{array}$ & Gene name & $\begin{array}{l}\text { Fold } \\
\text { change }\end{array}$ & $\begin{array}{l}\text { Accession } \\
\text { number }\end{array}$ & Gene name & $\begin{array}{l}\text { Fold } \\
\text { change }\end{array}$ \\
\hline M20881 & $\begin{array}{l}\text { Pregnancy specific beta-1- } \\
\text { glycoprotein } 1\end{array}$ & 70.43 & M64571 & $\begin{array}{l}\text { Microtubule-associated } \\
\text { protein } 4\end{array}$ & 0.32 \\
\hline AA216685 & $\begin{array}{l}\text { Prostate differentiation } \\
\text { factor }\end{array}$ & 18.88 & M11296 & $\begin{array}{l}\text { Colony-stimulating factor } 1 \\
\text { (macrophage) }\end{array}$ & 0.31 \\
\hline D87258 & $\begin{array}{l}\text { Protease, serine, } 11 \\
\text { (insulin-like growth } \\
\text { factor binding) }\end{array}$ & 17.27 & X07696 & Keratin 15 & 0.31 \\
\hline X52378 & $\begin{array}{c}\text { Carcinoembryonic antigen } \\
\text { gene family member } 6\end{array}$ & 16.80 & A304657 & $\begin{array}{l}\text { Peptidylprolyl isomerase A } \\
\text { (cyclophilin A) }\end{array}$ & 0.31 \\
\hline D58798 & Syndecan 1 & 10.23 & D45917 & $\begin{array}{l}\text { Tissue inhibitor of } \\
\text { metalloproteinase } 3\end{array}$ & 0.31 \\
\hline AF070612 & $\begin{array}{l}\text { Estrogen } \\
\text { sulfotransferase?? }\end{array}$ & 8.53 & U03877 & $\begin{array}{l}\text { Epidermal growth factor- } \\
\text { containing fibulin-like } \\
\text { extracellular matrix } \\
\text { protein } 1\end{array}$ & 0.30 \\
\hline U39050 & $\begin{array}{l}\text { Disabled (Drosophila) } \\
\text { homolog } 2\end{array}$ & 7.89 & L037652 & Ribosomal protein S20 & 0.30 \\
\hline X02761 & Fibronectin 1 & 7.87 & A131550 & $\begin{array}{l}\text { Homo sapiens ataxia- } \\
\text { telangiectasia group D- } \\
\text { associated protein mRNA, } \\
\text { complete cds }\end{array}$ & 0.30 \\
\hline D00169 & $\begin{array}{c}\text { Cytochrome P450, } \\
\text { subfamily XIA }\end{array}$ & 7.81 & U29953 & $\begin{array}{l}\text { Pigment epithelium-derived } \\
\text { factor }\end{array}$ & 0.29 \\
\hline AI004656 & $\begin{array}{l}\text { Placental growth factor } \\
\text { vascular endothelial } \\
\text { growth factor-related } \\
\text { protein }\end{array}$ & 7.33 & A876532 & Annexin A3 & 0.28 \\
\hline J05401 & $\begin{array}{l}\text { Creatine kinase, } \\
\text { mitochondrial } 2 \\
\text { (sarcomeric) }\end{array}$ & 6.00 & AI878886 & Heat shock $70 \mathrm{kD}$ protein 5 & 0.27 \\
\hline AI014497 & $\begin{array}{l}\text { Leukemia inhibitory } \\
\text { factor receptor }\end{array}$ & 5.91 & M57730 & Ephrin-A1 & 0.27 \\
\hline J03060 & $\begin{array}{l}\text { Glucosidase, beta; acid } \\
\text { (includes } \\
\text { glucosylceramidase) }\end{array}$ & 5.36 & A307373 & Keratin 7 & 0.27 \\
\hline
\end{tabular}




\begin{tabular}{|c|c|c|c|c|c|}
\hline $\begin{array}{l}\text { Accession } \\
\text { number }\end{array}$ & Gene name & $\begin{array}{l}\text { Fold } \\
\text { change }\end{array}$ & $\begin{array}{l}\text { Accession } \\
\text { number }\end{array}$ & Gene name & $\begin{array}{l}\text { Fold } \\
\text { change }\end{array}$ \\
\hline M15694 & $\begin{array}{l}\text { Alkaline phosphatase, } \\
\text { intestinal }\end{array}$ & 5.27 & X87212 & Cathepsin C & 0.26 \\
\hline M38180 & $\begin{array}{l}\text { Hydroxy-delta-5-steroid } \\
\text { dehydrogenase }\end{array}$ & 5.20 & AI380738 & $\begin{array}{l}\text { Ubiquitin carrier protein } \\
\text { E2-C }\end{array}$ & 0.26 \\
\hline AF023476 & $\begin{array}{l}\text { A disintegrin and } \\
\text { metalloproteinase } \\
\text { domain } 12 \\
\text { (ADAM12, meltrin } \\
\text { alpha) }\end{array}$ & 4.85 & M26326 & Keratin 18 & 0.26 \\
\hline D14043 & Sialomucin CD164 & 4.73 & L14721 & $\begin{array}{l}\text { Glutamyl aminopeptidase } \\
\text { (aminopeptidase A) }\end{array}$ & 0.26 \\
\hline Z98047 & Fibulin 1 & 4.70 & F061034 & $\begin{array}{l}\text { Tumor necrosis factor } \\
\text { alpha-inducible } \\
\text { cellular protein } \\
\text { containing leucine } \\
\text { zipper domains }\end{array}$ & 0.26 \\
\hline AI700706 & $\begin{array}{l}\text { General transcription } \\
\text { factor II, i, } \\
\text { pseudogene } 1\end{array}$ & 4.68 & U37100 & Aldose reductase-like 1 & 0.25 \\
\hline T29543 & $\begin{array}{l}\text { Luteinizing hormone } \\
\text { beta polypeptide }\end{array}$ & 4.61 & X56134 & Vimentin & 0.25 \\
\hline X76732 & Nucleobindin 2 & 4.49 & M63180 & $\begin{array}{l}\text { Threonyl-tRNA } \\
\text { synthetase }\end{array}$ & 0.24 \\
\hline X55740 & $5^{\prime}$ nucleotidase (CD73) & 4.37 & M83216 & Caldesmon 1 & 0.24 \\
\hline AI220927 & Inhibin, alpha & 4.37 & U59831 & $\begin{array}{l}\text { Forkhead (Drosophila)- } \\
\quad \text { like } 8\end{array}$ & 0.23 \\
\hline U83115 & Absent in melanoma 1 & 4.27 & M57230 & $\begin{array}{l}\text { Interleukin } 6 \text { signal } \\
\text { transducer (gp130) }\end{array}$ & 0.23 \\
\hline Z15108 & Protein kinase $\mathrm{C}$, zeta & 4.21 & X62570 & $\begin{array}{l}\text { Tryptophanyl-tRNA } \\
\text { synthetase }\end{array}$ & 0.22 \\
\hline
\end{tabular}

[The accession number and fold-change relative to time 0 is shown for each gene.]

the regulated genes into the nine patterns of gene expression is shown in Figure 5. Most of the induced genes exhibited patterns 1 and 2, while most of the repressed genes exhibited patterns 6 and 7 . 


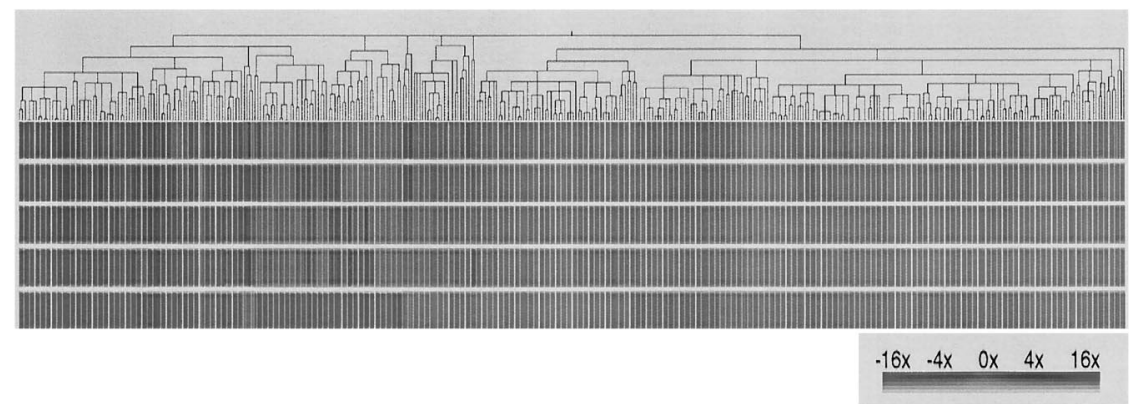

FIG. 4. Hierarchical tree cluster analysis of the 397 genes dynamically regulated during trophoblast differentiation. The code for the signal strength in the classification scheme is shown in the box at the bottom. [Adapted from Aronow BJ, Richardson BD, Handwerger S 2001 Microarray analysis of trophoblast differentiation: gene expression reprogramming in key gene function categories. Physiol Genomics 6:105-116.]

The observation that most genes that are dynamically regulated during differentiation exhibit rapid initiation of their transcriptional pattern strongly suggests that cytotrophoblast cells are poised to enter directly the differentiation process. Activation of the cytotrophoblast-to-syncytiotrophoblast gene program results from release of one or more sequential regulatory triggers. The mechanisms for gene activation or mRNA repression during trophoblast differentiation remain to be identified. Mechanisms could include both transcriptional and posttranscriptional activation of gene expression systems already in place within the cytotrophoblast cell or through the synthesis of new gene products that impact on gene expression. The different kinetic patterns may represent the occurrence of multiple regulatory mechanisms. Repression is particularly intriguing, since specific machinery for selective mRNA decay or accelerated turnover has not been described in the trophoblast cell.

\section{FUNCTIONAL CLASSIFICATION OF REGULATED GENES}

The dynamically regulated genes that were annotated or partially annotated were divided into six functional categories: cell and tissue structural dynamics (110 genes), cell cycle and apoptosis (21 genes), intercellular communication (45 genes), metabolism (79 genes), regulation of gene expression (85 genes), and unknown function (two genes). The distribution of the genes in the functional categories into different patterns of expression, as determined by K-means clustering, is shown in the lower panel of Figure 5. 


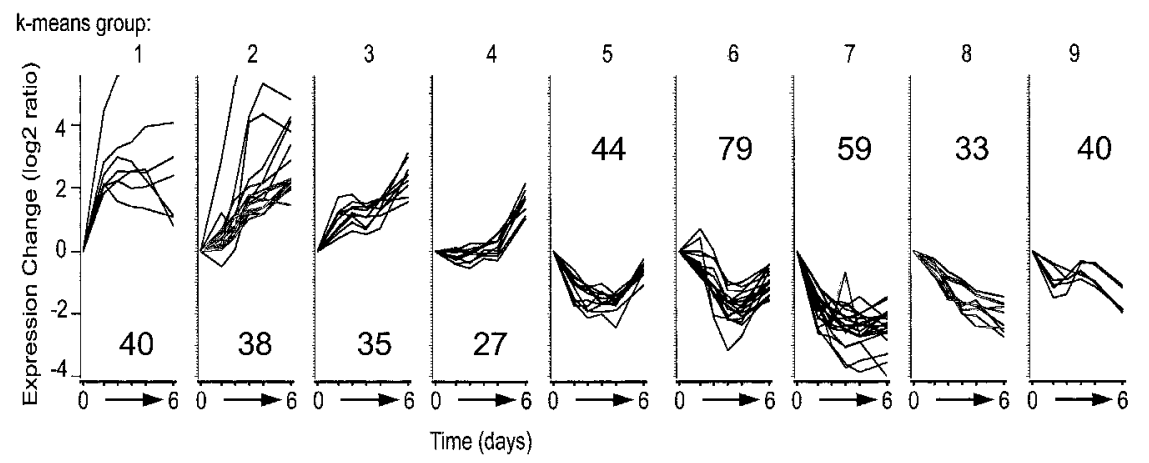

\begin{tabular}{lccccccccc} 
K-means group & 1 & 2 & 3 & 4 & 5 & 6 & 7 & 8 & 9 \\
\hline $\begin{array}{l}\text { Cell and tissue } \\
\text { structural dynamics }\end{array}$ & 8 & 7 & 2 & 3 & 13 & 31 & 17 & 13 & 13 \\
$\begin{array}{l}\text { Cell cycle and } \\
\text { apoptosis }\end{array}$ & 0 & 1 & 4 & 3 & 2 & 4 & 2 & 1 & 4 \\
$\begin{array}{l}\text { Intercellular } \\
\text { communication }\end{array}$ & 4 & 11 & 8 & 7 & 6 & 4 & 2 & 0 & 2 \\
$\begin{array}{l}\text { Intracellular } \\
\text { metabolism }\end{array}$ & 9 & 7 & 11 & 8 & 8 & 6 & 10 & 6 & 3 \\
$\begin{array}{l}\text { Regulation of } \\
\text { gene expression }\end{array}$ & 9 & 4 & 3 & 2 & 11 & 17 & 21 & 11 & 7
\end{tabular}

FIG. 5. K-means analysis of the 397 genes dynamically regulated during trophoblast differentiation. The K-means algorithm was applied to the $\log 2$ values for the ratio of each gene's expression. Nine patterns of gene expression were selected, with four patterns of induction and five patterns of repression. The total number of genes in each of the K-means patterns is indicated in the individual graphs. The lower panel indicates the distribution of the different functional categories of the genes within the different patterns of gene expression. [Adapted from Aronow BJ, Richardson BD, Handwerger S 2001 Microarray analysis of trophoblast differentiation: gene expression reprogramming in key gene function categories. Physiol Genomics 6:105-116.]

Each of the functional groups consisted of genes that were strongly induced and strongly repressed. For example, the category of cell and tissue structural dynamics contained six cell-adhesion genes that were induced prior to the aggregation and fusion of the cytotrophoblast cells and four adhesion genes that were induced at later times (Table II). In contrast, 24 of the 34 adhesion genes were repressed, with 10 of these belonging to pattern 6 . Among the genes involved in cytoskeletal organization, 17 of 21 were repressed, with seven exhibiting pattern 6. Some categories were composed of genes that were more uniformly induced or repressed. For example, most of the genes relating to intercellular communication were induced, with nine of the polypeptide hormone genes following a pattern identical to hPL, hCG $\alpha$, and hCG $\beta$ (pattern 2) (Table III). Many of the genes related to gene expression were repressed, including 27 of the 28 translation-related genes, 11 of which 
TABLE II

Patterns of Expression of Cell-adhesion Genes

\begin{tabular}{|c|c|c|c|}
\hline & Induced genes & & Repressed genes \\
\hline & Pattern 1 & & Pattern 5 \\
\hline X52378 & $\begin{array}{l}\text { Carcinoembryonic antigen } \\
\text { gene family member } 6\end{array}$ & X63629 & Cadherin 3, P-cadherin \\
\hline Z22555 & $\begin{array}{l}\text { CD36 antigen (collagen type I } \\
\text { receptor) }\end{array}$ & U03877 & $\begin{array}{l}\text { Epidermal growth factor-containing } \\
\text { fibulin-like extracellular matrix } \\
\text { protein } 1\end{array}$ \\
\hline Y00636 & $\begin{array}{l}\text { CD58 antigen (lymphocyte } \\
\text { function-associated antigen } \\
\text { 3) }\end{array}$ & AF047433 & Integrin beta 4 binding protein \\
\hline X02761 & Fibronectin 1 & U14391 & Myosin IC \\
\hline X51841 & Integrin, beta 4 & & \\
\hline \multirow[t]{3}{*}{ M20881 } & $\begin{array}{l}\text { Pregnancy specific beta-1- } \\
\text { glycoprotein } 1\end{array}$ & & Pattern 6 \\
\hline & & L36720 & Bystin-like \\
\hline & Pattern 2 & X79981 & Cadherin 5, VE-cadherin \\
\hline AF023476 & $\begin{array}{l}\text { A disintegrin and } \\
\text { metalloproteinase domain } 12 \\
\text { (meltrin alpha) }\end{array}$ & AI394286 & Desmocollin 2 \\
\hline AI683760 & Semaphorin 3B & Z26317 & Desmoglein 2 \\
\hline \multirow[t]{3}{*}{ D58798 } & Syndecan 1 & AF012023 & $\begin{array}{l}\text { Integrin cytoplasmic domain- } \\
\text { associated protein } 1\end{array}$ \\
\hline & & AI521645 & Integrin, alpha 2 (CD49B) \\
\hline & Pattern 3 & M35198 & Integrin, beta 6 \\
\hline \multirow[t]{6}{*}{ L11370 } & $\begin{array}{l}\text { Protocadherin } 1 \text { (cadherin-like } \\
\text { 1) }\end{array}$ & M61199 & Sperm-specific antigen 2 \\
\hline & & AL043034 & Sperm surface protein \\
\hline & & L12350 & Thrombospondin 2 \\
\hline & & & Pattern 7 \\
\hline & & AI310309 & CD24 antigen \\
\hline & & AL031058 & $\begin{array}{l}\text { Human desmoplakin mRNA, } 3^{\prime} \\
\text { end }\end{array}$ \\
\hline
\end{tabular}




\begin{tabular}{|c|c|c|}
\hline \multirow[t]{11}{*}{ Induced genes } & & Repressed genes \\
\hline & AF013711 & Transgelin \\
\hline & & Pattern 8 \\
\hline & N91557 & Cadherin 1, E-cadherin (epithelial) \\
\hline & X53586 & Integrin, alpha 6 \\
\hline & X16662 & Annexin A8 \\
\hline & & Pattern 9 \\
\hline & AA876532 & Annexin A3 \\
\hline & M24283 & $\begin{array}{l}\text { Intercellular adhesion molecule } 1 \\
\text { (CD54), human rhinovirus } \\
\text { receptor }\end{array}$ \\
\hline & AF000652 & $\begin{array}{l}\text { Syndecan binding protein } \\
\text { (syntenin) }\end{array}$ \\
\hline & X14787 & Thrombospondin 1 \\
\hline
\end{tabular}

[Patterns of gene expression were determined by K-means cluster analysis (see Figure 5). The accession number is given for each gene.]

followed pattern 7. However, genes for transcription and signal transduction molecules were split more evenly, with nine of 31 and eight of 26 exhibiting upregulated behavior, respectively.

\section{E. CATEGORICAL REPROGRAMMING}

The occurrence of strongly divergent behaviors within tightly related categories strongly suggests that functional reprogramming is necessary to accomplish differentiation. The efficient execution of some biologic processes (e.g., adhesion, tissue remodeling) is best accomplished through both the induction and repression of individual genes within the specific functional category. Our recent finding that human decidualization is also characterized by strong repression of many genes and strongly divergent behaviors within related categories further suggests that categorical reprogramming may be a fundamental process in the differentiation of many cell types (Figure 6) (Brar et al., 2001). Interestingly, comparison of genes activated and repressed in the differentiation of cytotrophoblast cells and decidual fibroblasts demonstrated limited overlap in their identities, with only 81 of 569 in common. Of these overlapping genes, many were reciprocally regulated. This indicates the unique identity of each cell type 
TABLE III

Patterns of Expression of Protein Hormone Gene

\begin{tabular}{|c|c|c|c|}
\hline & Induced genes & & Repressed genes \\
\hline & Pattern 1 & & Pattern 5 \\
\hline \multirow[t]{3}{*}{ AA033953 } & Prolactin receptor & M11296 & $\begin{array}{l}\text { Colony-stimulating factor } 1 \\
\text { (macrophage) }\end{array}$ \\
\hline & & M31159 & $\begin{array}{l}\text { Insulin-like growth factor binding } \\
\text { protein } 3\end{array}$ \\
\hline & Pattern 2 & M12783 & $\begin{array}{l}\text { Platelet-derived growth factor beta } \\
\text { polypeptide }\end{array}$ \\
\hline AF055008 & $\begin{array}{l}\text { AF055008 granulin }\{\text { Incyte } \\
\text { PD:812141\} }\end{array}$ & & \\
\hline U50330 & Bone morphogenetic protein 1 & & Pattern 6 \\
\hline X51801 & $\begin{array}{l}\text { Bone morphogenetic protein } 7 \\
\quad(\text { osteogenic protein } 1)\end{array}$ & Y12084 & $\begin{array}{l}\text { Insulin-like growth factor binding } \\
\text { protein } 10\end{array}$ \\
\hline R68866 & $\begin{array}{l}\text { Human chorionic } \\
\text { gonadotropin alpha }\end{array}$ & & \\
\hline M54963 & $\begin{array}{l}\text { Human chorionic } \\
\text { gonadotropin beta }\end{array}$ & & Pattern 7 \\
\hline Mn_001317 & Placental lactogen & M73238 & Ciliary neurotrophic factor receptor \\
\hline T29543 & $\begin{array}{l}\text { Luteinizing hormone beta } \\
\text { polypeptide }\end{array}$ & & \\
\hline AI004656 & $\begin{array}{l}\text { Placental growth factor, } \\
\text { vascular endothelial growth } \\
\text { factor-related protein }\end{array}$ & & Pattern 8 \\
\hline \multirow[t]{2}{*}{ AA216685 } & Prostate differentiation factor & J05008 & Endothelin 1 \\
\hline & Pattern 3 & & \\
\hline \multirow[t]{2}{*}{ AI014497 } & $\begin{array}{l}\text { Leukemia inhibitory factor } \\
\text { receptor }\end{array}$ & & \\
\hline & Pattern 4 & & \\
\hline V00571 & $\begin{array}{l}\text { Corticotropin-releasing } \\
\text { hormone }\end{array}$ & & \\
\hline AI220927 & Inhibin, alpha & & \\
\hline S83157 & Natriuretic peptide receptor B & & \\
\hline
\end{tabular}

[Patterns of gene expression were determined by K-means cluster analysis (see Figure 5). The accession number is given for each gene.] 


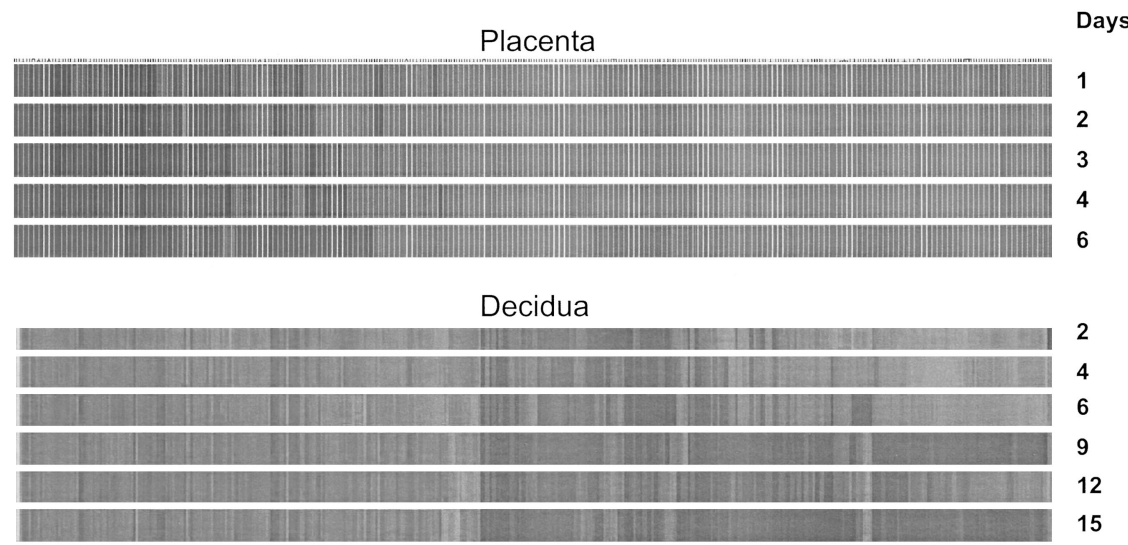

$-16 \times-4 \times \quad 0 \times \quad 4 \times \quad 16 x$

FIG. 6. Comparison of hierarchical tree analysis of the genes dynamically regulated during trophoblast differentiation and the decidualization of human decidual fibroblasts. The code for the signal strength in the classification schemes is shown in the boxes at the bottom. [Adapted from Brar AK, Handwerger S, Kessler CA, Aronow BJ 2001 Gene induction and categorical reprogramming during in vitro human endometrial fibroblast decidualization. Physiol Genomics 7:135-148.]

as well as the specificity of the differentiation program that each follows. A large number of the genes in both models are related to cell and tissue structure and cell-cell interaction.

\section{F. PROPOSED SCHEME OF VILLOUS CYTOTROPHOBLAST DIFFERENTIATION CORRELATING PATTERNS OF GENE FUNCTION TO MORPHOLOGICAL CHANGES}

The occurrence of distinct temporal behaviors for gene activation and repression within different functional categories correlated well with the progressive morphological changes that underlie trophoblast differentiation (Figure 7). Thirty annotated genes were induced and 75 annotated genes were repressed during the time that the cells were aggregating and fusing. However, prior to the greatest induction of hPL and hCG, 32 annotated genes were induced with a delayed pattern similar to that of $\mathrm{hPL}, \mathrm{hCG} \alpha$, and $\mathrm{hCG} \beta$. During this early stage of differentiation, many specialized adhesion genes were induced (pregnancyspecific glycoprotein 1, carcinoembryonic antigen family member 6, fibronectin 1, integrin B4, C58, and C36) as well as ADAM 12. ADAM 12 is a member of the ADAM (a disintegrin and a metalloproteinase domain) family of tissuespecific fusogenic proteins that play a key role in cell-cell fusion, especially in 


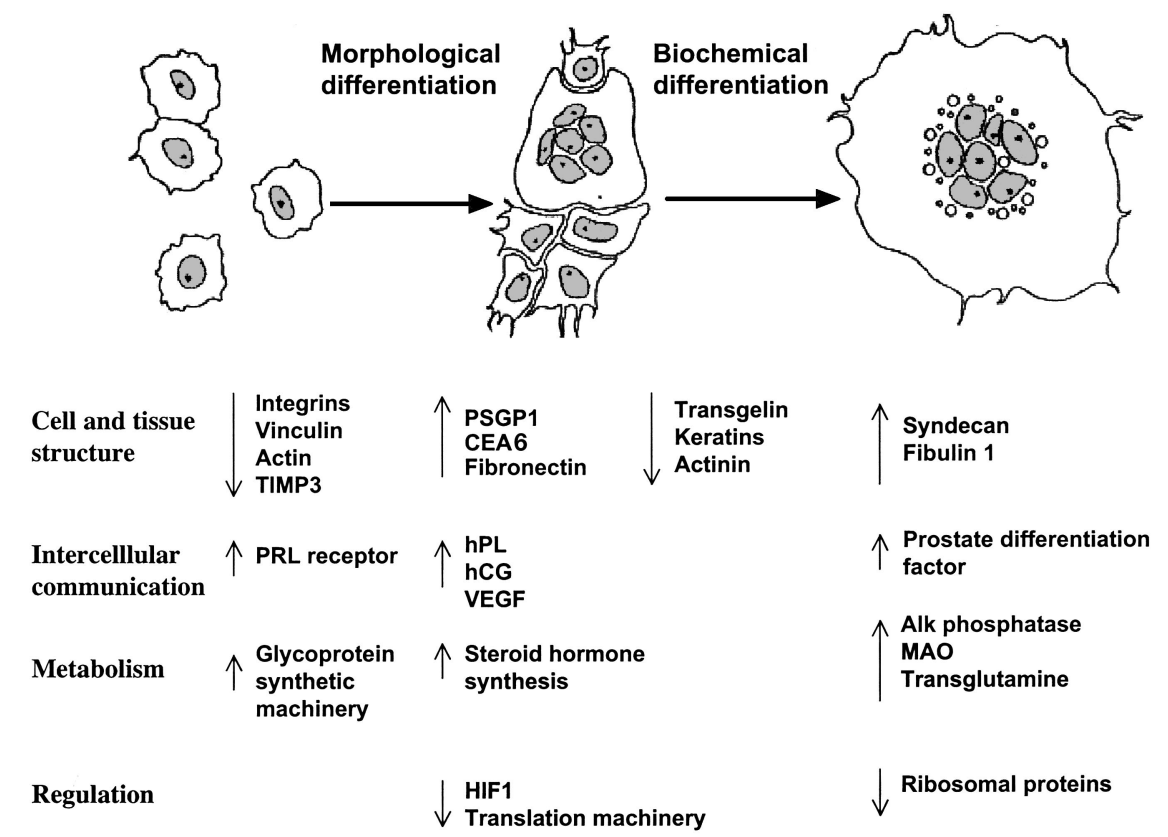

FIG. 7. Categorical reprogramming-based scheme for cytotrophoblastic differentiation. Major genes and functional groups that exhibit dynamic expression changes are depicted in relationship to the morphological changes that accompany syncytiotrophoblast cell formation during the 6-day culture period. The genes and functional groups are taken from Table III. Integrins refers to integrins $\alpha 6$ and $\beta 6$. Adhesion proteins refer to cadherin 1,3, and 5; annexins A3 and A8; CD24; and transgelin. TIMP3, tissue inhibitor of metalloproteinase 3; CEA6, carcinoembryonic antigen gene family member 6; VEGF, vascular endothelial growth factor; HIF1, hypoxia inducible factor 1; $\mathrm{MAO}$, monamine oxidase A. We hypothesize that categorical reprogramming of gene expression occurs, particularly within the category of cell and tissue structure genes, which is necessary to accomplish the marked cell morphology changes that occur during trophoblast differentiation. Categorical reprogramming represents the simultaneous activation, repression, or degradation of mRNAs from within a given functional group. [Top panel (diagram of cellular morphology changes) is adapted with permission from Kliman HJ, Nestler JE, Sermasi E, Sanger JM, Strauss JF III 1986 Purification, characterization, and in vitro differentiation of cytotrophoblasts from human term placentae. Endocrinology 118:1567-1582. Copyright The Endocrine Society. Bottom panel is reprinted from Aronow BJ, Richardson BD, Handwerger S 2001 Microarray analysis of trophoblast differentiation: gene expression reprogramming in key gene function categories. Physiol Genomics 6:105-116.]

skeletal muscle and bone. In addition, genes for the long form of the prolactin receptor, hydroxy-delta-5-steroid dehydrogenase and endoglin, a component of the TGF $\beta$ receptor complex that binds $\beta_{1}$ and $\beta_{3}$ isoforms, were induced in the cytotrophoblast cells early in differentiation. Absent in melanoma 1 (AIM1), a novel, nonlens member of the $\beta \gamma$-crystallin superfamily associated with the 
control of tumorigenicity in human malignant melanoma, also was induced prior to cell aggregation and fusion.

Following syncytial formation, there was marked induction of genes involved in intercellular communication. These included genes for nine polypeptide hormone genes: $\mathrm{hPL}, \mathrm{hCG} \alpha, \mathrm{hCG} \beta$, luteinizing hormone (LH) $\beta$, granulin, vascular endothelial growth factor (VEGF)-related protein, and three members of the TGF $\beta$ superfamily (prostate differentiation factor, bone morphogenetic protein-1 (BMP-1), and BMP-7, also known as osteogenic protein 1). BMP-7 and BMP-1 play strong roles in the development and differentiative transformation of many organ systems. Corticotropin-releasing hormone (CRH), which is known to be a specific marker for terminally differentiated syncytiotrophoblast cells, was not significantly induced until day 4, following inductions of hPL and hCG. Expression of genes for insulin-like growth factor binding protein-3 (IGFBP-3) and IGFBP-10 were repressed. Surprisingly, CSF-1, which is known to induce trophoblast differentiation in vitro, also was repressed.

\section{Summary and Conclusions}

In summary, we have identified a temporal event sequence that underlies cytotrophoblast differentiation, based on the induction and repression of a series of genes not recognized previously to play a role in placental development. We have shown that cytotrophoblast-to-syncytiotrophoblast cell differentiation is comprised of a highly dynamic gene program that significantly affects the mRNA levels of nearly 400 of 7000 individual genes queried. Several distinct kinetic patterns of gene induction and repression were observed. Repression was a highly significant phenomenon but its mechanism is unclear. Two possible mechanisms are selective degradation of a subgroup of mRNAs or strong transcriptional repression coupled with relatively high constitutive mRNA turnover. We have termed the phenomena of simultaneous induction and repression of genes with similar function as categorical reprogramming. We hypothesize that trophoblast differentiation requires both activation and repression of a substantial number of genes. We further postulate the existence of two classes of gene regulatory processes that are necessary to accomplish cellular differentiation. The first is the induction of gene products that are responsible for cell functions that were not necessary prior to differentiation but subsequently are required for differentiated cell functions. Examples would include hormone production, unique metabolic processes, or mediators of differentiation per se. The other class represents induction of genes that replace existing gene products with those that cause the cell to switch structure and function. To accomplish this, we envision that the cell must eliminate mRNAs of gene products that could compete or interfere with the induced gene set. Successful accomplishment of 
cellular differentiation may require both the induction of the effectors of the differentiated cell and dynamic reprogramming of genes within functional pathways that are critical for precursor and product cell lineages.

\section{ACKNOWLEDGMENTS}

We thank Brian Richardson, Michael Hubert, and Sarah Williams for technical assistance. Our research was supported by National Institutes of Health grant HD-07447.

\section{REFERENCES}

Aronow BJ, Richardson BD, Handwerger S 2001 Microarray analysis of trophoblast differentiation: gene expression reprogramming in key gene function categories. Physiol Genomics 6:105-116

Benirschke K, Kaufmann P 1995 Early development of the human placenta. In: Benirschke K, Kaufmann P, eds. Pathology of the Human Placenta. New York: Springer-Verlag; 49-56

Bischof P, Haenggeli L, Campana A 1995 Effect of leukemia inhibitory factor on human cytotrophoblast differentiation along the invasive pathway. Am J Reprod Immunol 34: 225-230

Boime I 1991 Human placental lactogen production is linked to the stage of trophoblast differentiation. In: Miller RK, Thiede HA, eds. Trophoblast Research. Rochester, NY: Plenum Medical; 57-60

Brar AK, Handwerger S, Kessler CA, Aronow BJ 2001 Gene induction and categorical reprogramming during in vitro human endometrial fibroblast decidualization. Physiol Genomics $7: 135-148$

Cross JC 2000 Genetic insights into trophoblast differentiation and placental morphogenesis. Semin Cell Dev Biol 11:105-113

Dizon-Townson DS, Lu J, Morgan TK, Ward KJ 2000 Genetic expression by fetal chorionic villi during the first trimester of human gestation. Am J Obstet Gynecol 183:706-711

Feinberg RF, Kliman HJ, Wang CL 1994 Transforming growth factor-beta stimulates trophoblast oncofetal fibronectin synthesis in vitro: implications for trophoblast implantation in vivo. J Clin Endocrinol Metab 78:1241-1248

Garcia-Lloret MI, Morrish DW, Wegmann TG, Honore L, Turner AR, Guilbert LJ 1994 Demonstration of functional cytokine-placental interactions: CSF- 1 and GM-CSF stimulate human cytotrophoblast differentiation and peptide hormone secretion. Exp Cell Res 214: $46-54$

Ho S, Winkler-Lowen B, Morrish DW, Dakour J, Li H, Guilbert LJ 1999 The role of Bcl-2 expression in EGF inhibition of TNF-alpha/IFN-gamma- induced villous trophoblast apoptosis. Placenta 20:423-430

Hoshina M, Hussa R, Pattillo R, Camel HM, Boime I 1984 The role of trophoblast differentiation in the control of the hCG and hPL genes. Adv Exp Med Biol 176:299-312

Kliman HJ, Nestler JE, Sermasi E, Sanger JM, Strauss JF III 1986 Purification, characterization, and in vitro differentiation of cytotrophoblasts from human term placentae. Endocrinology 118:1567-1582

Knofler M, Vasicek R, Schreiber M 2001 Key regulatory transcription factors involved in placental trophoblast development - a review. Placenta 22(suppl A):S83-S92

Maruo T, Matsuo H, Otani T, Mochizuki M 1995a Role of epidermal growth factor (EGF) and its receptor in the development of the human placenta. Reprod Fertil Dev 7:1465-1470 
Maruo T, Murata K, Matsuo H, Samoto T, Mochizuki M 1995b Insulin-like growth factor-I as a local regulator of proliferation and differentiated function of the human trophoblast in early pregnancy. Early Pregnancy 1:54-61

Morrish DW, Bhardwaj D, Paras MT 1991 Transforming growth factor beta 1 inhibits placental differentiation and human chorionic gonadotropin and human placental lactogen secretion. Endocrinology 129:22-26

Morrish DW, Linetsky E, Bhardwaj D, et al. 1996 Identification by subtractive hybridization of a spectrum of novel and unexpected genes associated with in vitro differentiation of human cytotrophoblast cells. Placenta 17:431-441

Morrish DW, Dakour J, Li H 1998 Functional regulation of human trophoblast differentiation. J Reprod Immunol 39:179-195

Nachtigall MJ, Kliman HJ, Feinberg RF, Olive DL, Engin O, Arici A 1996 The effect of leukemia inhibitory factor (LIF) on trophoblast differentiation: a potential role in human implantation. J Clin Endocrinol Metab 81:801-806

Pollard JW, Bartocci A, Arceci R, Orlofsky A, Ladner MB, Stanley ER 1987 Apparent role of the macrophage growth factor, CSF-1, in placental development. Nature 330:484-486

Richards RG, Hartman SM, Handwerger S 1994 Human cytotrophoblast cells cultured in maternal serum progress to a differentiated syncytial phenotype expressing both human chorionic gonadotropin and human placental lactogen. Endocrinology 135:321-329

Richardson BD, Cheng YH, Langland RA, Handwerger S 2001 Differential expression of AP-2gamma and AP-2alpha during human trophoblast differentiation. Life Sci 69:2157-2165

Ringler GE, Strauss JF III 1990 In vitro systems for the study of human placental endocrine function. Endocr Rev 11:105-123

Scott IC, Anson-Cartwright L, Riley P, Reda D, Cross JC 2000 The HAND1 basic helix-loophelix transcription factor regulates trophoblast differentiation via multiple mechanisms. Mol Cell Biol 20:530-541

Shi QJ, Lei ZM, Rao CV, Lin J 1993 Novel role of human chorionic gonadotropin in differentiation of human cytotrophoblasts. Endocrinology 132:1387-1395

Sibley CP 1998 Placental nutrient transport. In Knobil E, Neill JD, eds. Encyclopedia of Reproduction. San Diego: Academic Press; 883

Stephanou A, Handwerger S 1995a Retinoic acid and thyroid hormone regulate placental lactogen expression in human trophoblast cells. Endocrinology 136:933-938

Stephanou A, Handwerger S 1995b The nuclear factor NF-IL6 activates human placental lactogen gene expression. Biochem Biophys Res Commun 206:215-222

Wice B, Menton D, Geuze H, Schwartz AL 1990 Modulators of cyclic AMP metabolism induce syncytiotrophoblast formation in vitro. Exp Cell Res 186:306-316

Xu B, Lin L, Rote NS 1999 Identification of a stress-induced protein during human trophoblast differentiation by differential display analysis. Biol Reprod 61:681-686 